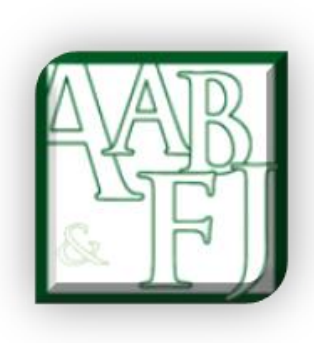

\title{
Editorial Volume 14 Issue 5
}

\author{
Ciorstan Smark ${ }^{1}$ and Monir Mir ${ }^{2}$
}

This issue of AABFJ brings together five articles from a variety of accounting and finance backgrounds. Some housekeeping matters are also covered towards the end of this Editorial. From finance, Al-Dmour, Zaiden and Abdulrahman (2020) investigates whether foreign institutional investors respond to target price revisions. Franceschetti (2020) examines earnings management at times of financial crisis. Accounting articles are also front and centre in this issue.

Bhattacharya and Mittal (2020) look at aspects of the Acquired Needs Theory as they play out in the responses of people working at home during the COVID 19 pandemic. From auditing, Nehme, Michael, and Haslam (2020) analyse different factors potentially involved in influencing the size of audit fees. Board of Directors' characteristics are found to have a significant relation to audit fees. Economics is also represented in this issue.

Ece and Sayılgan (2020) investigate the possible links between economic factors and financial distress in Turkey. Some AABFJ housekeeping issues are also discussed in this Editorial.

Editorials in the recent past of AABFJ have discussed such issues as innovation (Damayanti, Smark \& and Mir, 2020), the importance of the environment and sustainability (de Silva Lokuwaduge, Smark \& Mir, 2019; Smark \& Mir, 2019) as well as social responsibility (Mir \& Smark, 2019). In light of keeping our journal practices in line with the tenor of the articles that we publish and support, we would like to suggest that we no longer print paper copies of any journal other than those required by the Australian repositories and Authors whose institutions require a hard copy of $\mathrm{AABFJ}$ as evidence of publication. The idea of this is to respect the environment and behave in a responsible way given the financial strictures of COVID 19. Nonetheless, we will provide printed copies to Authors on request.

Another issue that is being considered in AABFJ is whether to open an accounting and finance history strem. The idea being debated is to set aside one issue per year to publish history related articles from the fields of accounting, economics, Finance, Financial planning and banking. Your feedback on this idea will be appreciated. Please send your feedback to AABFJournal @gmail.com.

\footnotetext{
${ }^{1}$ University of Wollongong, Australia

${ }^{2}$ University of Canberra, Australia
} 


\section{References}

Al-Dmour, Ahmed; Zaidan, Hala; and Alnatour, Abdulrahman, The Usefulness of Analysts' Target Prices to Foreign Institutional Investors: U.S. Evidence, Australasian Accounting, Business and Finance Journal, 14(5), 2020, 42-64. doi:10.14453/aabfj.v14i5.4

Bhattacharya, Sonali and Mittal, Priyanka, The Impact of Individual Needs on Employee Performance while Teleworking, Australasian Accounting, Business and Finance Journal, 14(5), 2020, 65-85. doi:10.14453/aabfj.v14i5.5

Damayanti, Cacik Rut; Smark, Ciorstan; and Mir, Monir, Special Issue on Business and Public Administration in Indonesia: Advancing Business and Public Administration in the Age of Innovation, Australasian Accounting, Business and Finance Journal, 14(1), 2020, 1-4. doi:10.14453/aabfj.v14i1.1

de Silva Lokuwaduge, Chitra S.; Smark, Ciorstan; and Mir, Monir, Sustainable Development Goals and Businesses as Active Change Agents, Australasian Accounting, Business and Finance Journal, 14(3), 2020, 1-5. doi:10.14453/aabfj.v14i3.1

Ece, Arslan and Sayılgan, Güven, Macroeconomic Determinants of Financial Distress in Turkey: An Econometric Analysis, Australasian Accounting, Business and Finance Journal, 14(5), 2020, 86-107. doi:10.14453/aabfj.v14i5.6

Franceschetti, Bruno, Financial Crisis: Time to Manage Earnings?, Australasian Accounting, Business and Finance Journal, 14(5), 2020, 26-41. doi:10.14453/aabfj.v14i5.3

Mir, Monir and Smark, Ciorstan, Editorial: AABFJ Volume 13, Issue 1, 2019, Australasian Accounting, Business and Finance Journal, 13(1), 2019, 1-3. doi:10.14453/aabfj.v13i1.1

Nehme, Rabih; Michael, Amir; and Haslam, Jim, Directors' Monitoring Role, Ownership Concentration and Audit fees, Australasian Accounting, Business and Finance Journal, 14(5), 2020, 3-25. doi:10.14453/aabfj.v14i5.2

Smark, Ciorstan and Mir, Monir, Special Issues in the Australasian Accounting, Business and Finance Journal 2018 and 2019, Australasian Accounting, Business and Finance Journal, 13(4), 2019, 1-3. doi:10.14453/aabfj.v13i4.1 